\title{
NEW SERBIAN RECORDS OF THE SLUG TANDONIA KUSCERI (H. WAGNER, 1931) (GASTROPODA: EUPULMONATA: MILACIDAE) SUGGEST ITS CONTINUOUS DISPERSAL TO THE NORTH
}

\author{
VUKAŠIN ZORAN GOJŠINA
}

\begin{abstract}
Department of Morphology, Systematics and Phylogeny of Animals, University of Belgrade, Faculty of Biology, Studentski trg 16, 11000, Belgrade, Serbia (e-mail: mr.gojsinavukasin@gmail.com);

(D) https://orcid.org/0000-0002-0413-9304
\end{abstract}

\begin{abstract}
Tandonia kusceri (H. Wagner) is a terrestrial slug native to the Balkan Peninsula (S. Serbia, N. Macedonia, Bulgaria and Dobrudja region of Romania) and the European part of Turkey. In Serbia, it was known mostly from the southern regions. The northernmost locality (Palić settlement, near Subotica) reported here suggests that the slug's distribution is nearly continuous from its native range until Slovakia. The new record was first recognised from the pictures posted on a Facebook group for insect identification in 2021. The identification was subsequently confirmed by anatomical examination. This further emphasises the importance of social media in monitoring the spread of invasive invertebrates.
\end{abstract}

KEY WORDS: slug dispersal; slug anatomy; geographical distribution; social media

\section{INTRODUCTION}

Tandonia kusceri (H. Wagner, 1931) is a terrestrial slug native to the Balkan Peninsula (southern Serbia, North Macedonia, Bulgaria and Dobrudja region in Romania) and the European part of Turkey (GROssU 1983, REISCHÜTZ 1988, WIKTOR 1996, DEDOV \& MITEV 2011).

T. kusceri has been introduced to various regions such as Ukraine (SON 2004, 2010), Crimea (LEONOV 2007), Russia (SYSOEV \& SCHILEYKO 2009), Moldova (BALASHOV et al. 2013), Slovakia (KORÁBEK et al. 2016), Greece (GEORGIEV 2017) and the countries of former Yugoslavia, excluding Serbia and N. Macedonia, such as Croatia and Montenegro (WIKTOR 1996, TELEBAK et al. 2013). Recently it has been also reported from Hungary, where it is already widespread (TURÓcI et al. 2020). Outside Europe, it has been introduced in North America, Illinois, USA (GERBER 2014).

In Serbia, the species is known to occur in the south (Sveta Petka Monastery near Niš, the type locality, Peć in Kosovo and Užice) and in the north (Belgrade and the Special Nature Reserve Zasavica) (WiKTOR 1996, TELEBAK \& STANKOVIĆ 2007). Here we discuss a new record of T. kusceri from northern Serbia, close to the Hungarian border, first discovered from pictures posted on April 21st 2021 on a Facebook group for insect identification named "Insekti Srbije (Insects of Serbia)".

\section{MATERIAL AND METHODS}

The locality of the specimens identified from the photo is Palić settlement near Subotica $\left(46^{\circ} 06^{\prime} 24.7^{\prime \prime} \mathrm{N}\right.$, $\left.19^{\circ} 44^{\prime} 53.2^{\prime \prime E}\right) ; 10$ specimens were found on April 21st, 2021 by TIJANA TUMBAS (citizen scientist) in a house yard around bricks and on the soil. 
The locality of the dissected specimen is Palić settlement $\left(46^{\circ} 06^{\prime} 06.34^{\prime \prime} \mathrm{N}, 19^{\circ} 46^{\prime} 39.70^{\prime \prime} \mathrm{E}\right)$, one specimen collected by the author on September 23rd, 2021 and preserved in 70\% ethanol. The specimen was found near an abandoned house among stones and under leaves together with many specimens of Limax maximus Linnaeus, 1758.

Other specimens examined: Belgrade (several localities near river Sava), Mladenovac (municipality in Belgrade), Kovin settlement (house yard, $50 \mathrm{~km}$

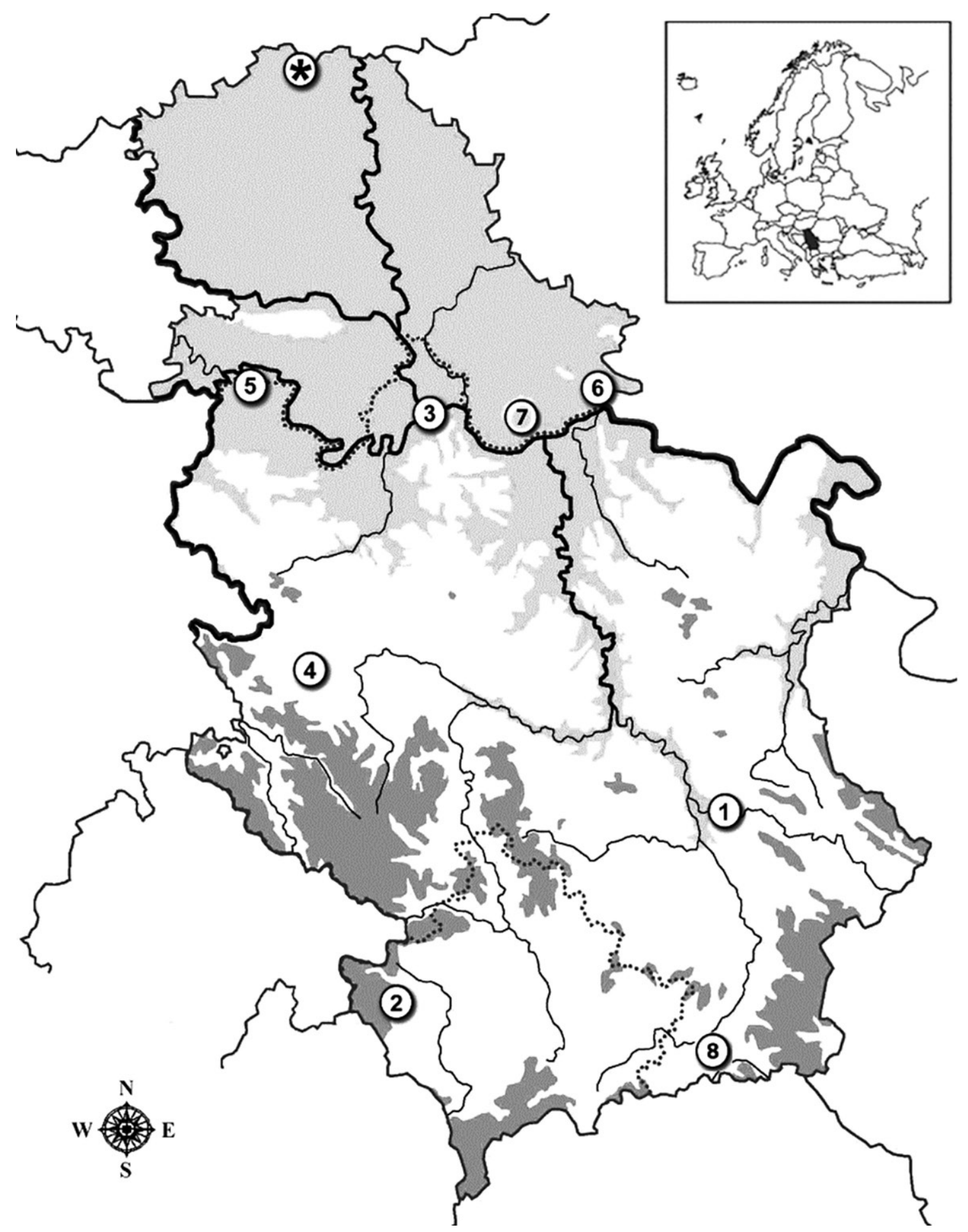

Fig. 1. Distribution of Tandonia kusceri (H. Wagner, 1931) in Serbia. 1 - Niš; 2 - Peć (Kosovo); 3 - Belgrade; 4 - Užice; 5 - Zasavica; 6 - Bela Crkva; 7 - Kovin; 8 - Prohor Pčinjski; * - Palić, near Subotica. According to WIKTOR (1987) there is a "dense network" of localities in the southern parts of the country. Since these localities are not specified, they are not included in this map 
from Belgrade), Bela Crkva settlement (95 km from Belgrade) and Prohor Pčinjski monastery (S. Serbia).

Dissection and photographing of the genitalia were carried out using Nikon SMZ800N stereomicroscope equipped with a Nikon DS-Fi2 camera. A Nikon DS-L3 control unit was used for setting scale bars.

\section{RESULTS AND DISCUSSION}

T. kusceri is distinct in some external and anatomical features. Its body length is up to $100 \mathrm{~mm}$ when fully extended; the colouration is very variable, mostly pink-brown or ash-grey-pink with small blackish spots (this colouration can change considerably after preservation). The keel is distinct, pale and without any spots, hardly visible after preservation; the mucus is colourless and thick, but when the slug is irritated, it can become milky-white; the head and tentacles are black. The slug has some unique anatomical traits such as very long vas deferens; very long epiphallus (5-6 times longer than penis) which is coiled and internally papillated; short penis divided into proximal and distal parts, the proximal section cylindrical, the distal section enlarged and with a large penial papilla. The penis retractor muscle is thin and attached between the penis and epiphallus; vagina very short (WIKTOR 1987, 1996, KORÁBEK et al. 2016, TURÓcI et al. 2020).

T. kusceri can be confused with several other species such as Tandonia rustica (Millet, 1843) and T. serbica (H. Wagner, 1930). It differs from T. rustica in its less slender and darker body, and longer epiphallus and from $T$. serbica in its larger size, absence of black spots on the back and longer epiphallus (WIKTOR 1996). T. kusceri is often found sympatrically with T. serbica so that WIKTOR (1996) wondered if they
The slug was identified based on its body colouration and genital morphology following WIKTOR (1987, 1996), KORÁBEK et al. (2016) and TURÓCI et al. (2020).

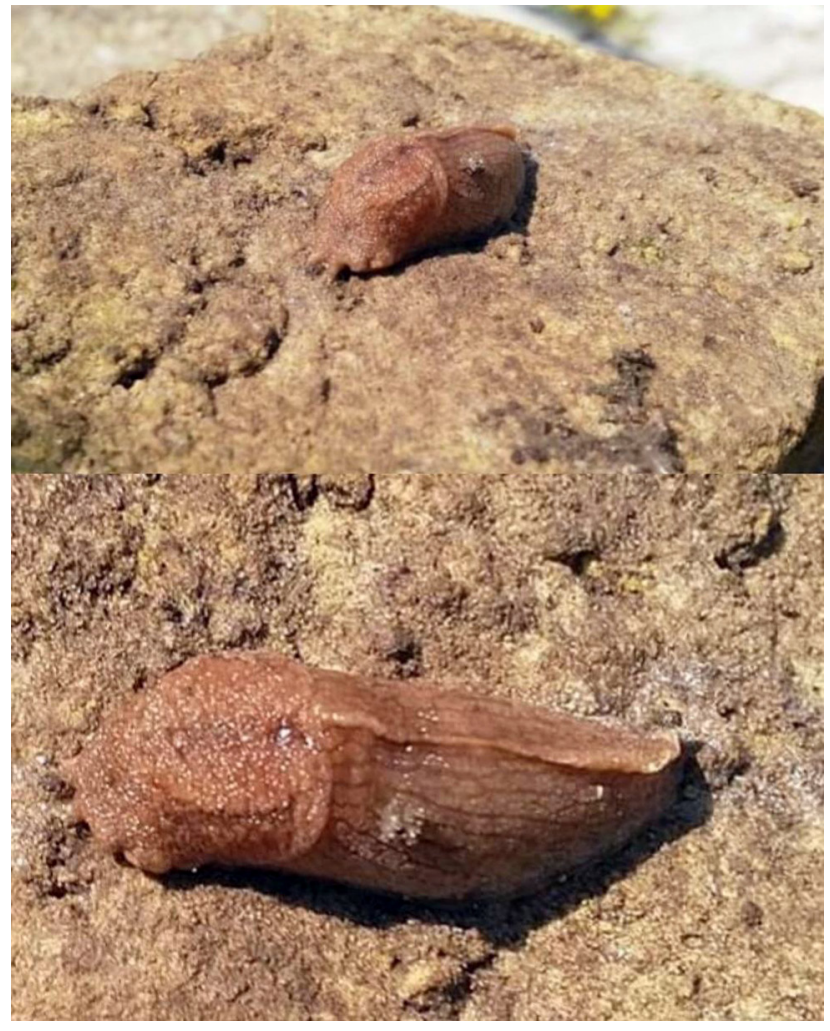

Fig. 2. Tandonia kusceri (H. Wagner, 1931). Palić settlement near Subotica. Photo: T. TUMBAS

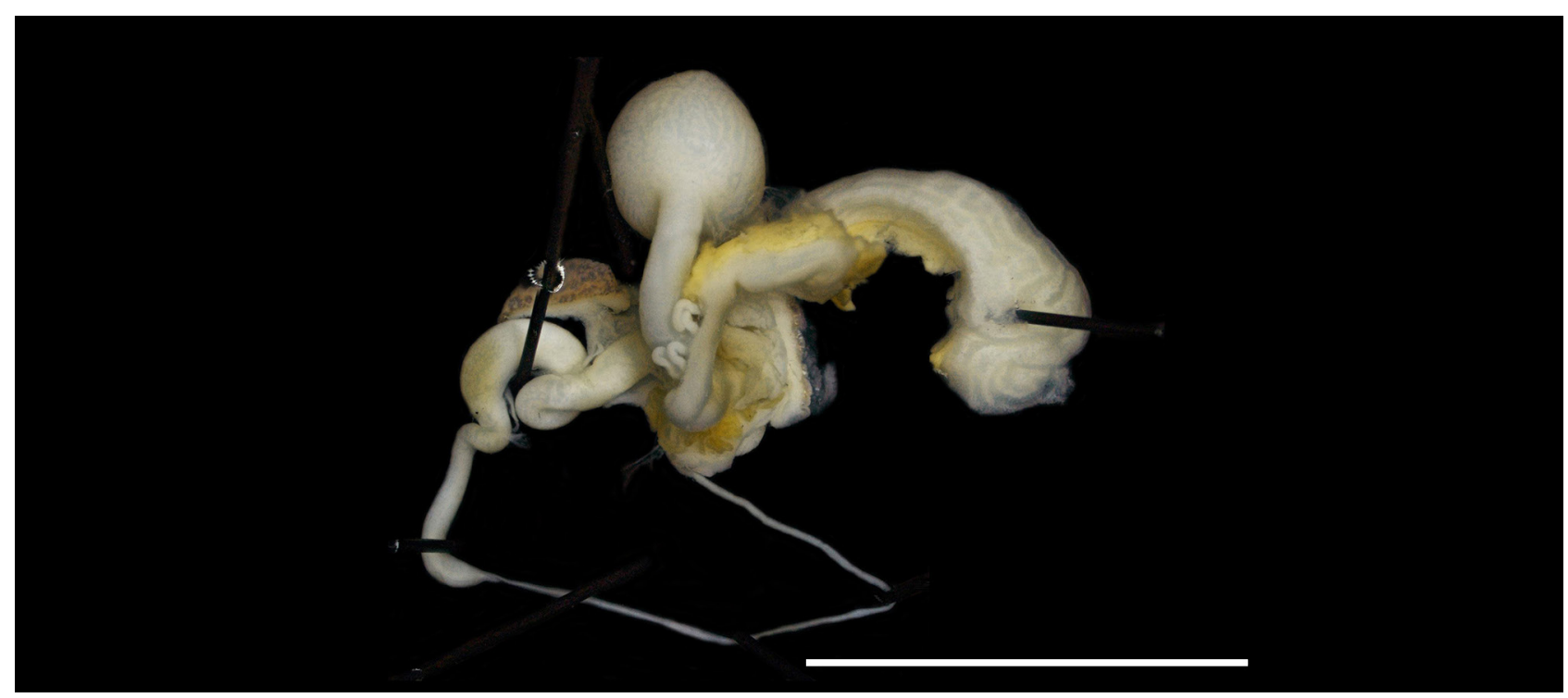

Fig. 3. Genital anatomy of Tandonia kusceri (H. Wagner, 1931). Scale bar $10 \mathrm{~mm}$ 
might represent forms or stages of sexual maturation of the same species. T. kusceri is characterised by a wide ecological tolerance and is often found as a synanthrope near shrubs, in forests or under stones and rubble in large numbers (WIKTOR 1996, WeLTERSCHULTES 2012).

I found the species at several localities in Serbia: Belgrade and its environs, and Mladenovac (municipality in Belgrade) where it is the most frequent slug together with L. maximus. T. kusceri was also found in Kovin and Bela Crkva settlements, while in Kovin it co-occurred with $L$. maximus which was much more numerous. The species was also recorded in Prohor Pčinjski monastery (near the border with $\mathrm{N}$. Macedonia) which is the southernmost known locality of this species from the territory of Serbia (Fig. 1).

The specimens reported here correspond very well to T. kusceri with respect of colouration (Fig. 2) and the specimen from the northern site (Palić) also with respect to its anatomical characters. Indeed it has a very long vas deferns and very long epiphallus as reported in this milacid (Fig. 3).

The first record of T. kusceri in Slovakia was interpreted as another example of a Southern European species being introduced in a Central European capital as a result of intensive commercial transport (KorÁBEK et al. 2016). The discovery that this slug was already widespread in Hungary when in was first

\section{REFERENCES}

BALASHOV I. A., MikHAil O. S., ViORICA C., WelteRSCHUltes F. W. 2013. An updated annotated checklist of the molluscs of the Republic of Moldova. Folia Malacologica 21: 175-181.

https://doi.org/10.12657/folmal.021.021

Dedov I. K., MiteV T. 2011. Mollusks fauna (Mollusca: Gastropoda: Bivalvia) of Mountain Osogovo. Acta Zoologica Bulgarica 63: 37-46.

GEORGIEV D. 2017. Updated and corrected list of the inland molluscs of Samothraki Island (N Aegean, Greece). ZooNotes 113: 1-4.

GERBER J. 2014. First American record of the exotic slug Tandonia kusceri (Gastropoda: Milacidae). The Nautilus 128: 59-63.

Grossu A. V. 1983. Gastropoda Romaniae. 4. Ordo Stylommatophora. Suprafam.: Arionacea, Zonitacea, Ariophantacea şi Helicacea. Editura Litera, Bucureşti.

KORÁBEK O., ČEJKA T., JUŘIČKOVÁ L. 2016. Tandonia kusceri (Pulmonata: Milacidae), a slug new for Slovakia. Malacologica Bohemoslovaca 15: 3-8.

LEONOV S. V. 2007. The first record of the Tandonia kusceri (Pulmonata, Milacidae) in Crimea and a few remarks about its natural habitats. Vestnik Zoologii 41: 142.

PÁll-Gergely B., Majoros G., DOMOKos T., JuhÁsz A., TURÓCI Á., BADACSONYI L., FEKETE J., ASAMI T. 2019. reported made it clear that it was not distributed only in large cities (TURÓCI et al. 2020). Furthermore, it was speculated that T. kusceri would spread from its native range to the north continuously, which suggests that its invasion is at least partly natural. The present record from Palić in northern Serbia, supports this view showing that the distribution of this slug is continuous from its native range to the newly reached more northern areas.

This new and important record was recognised in a Facebook group specialising in insect identification. This emphasises the importance of citizen science contribution in monitoring of the spread of invasive species as stated by PÁLL-GERGELY et al. (2019).

\section{ACKNOWLEDGEMENTS}

I thank TIJANA TUMBAS (citizen scientist) for the photos of the specimen, MIHAILO VuJIĆ for collecting the specimen from Prohor Pčinjski monastery, TAMARA KARAN-ŽNIDARŠIČ (University of Belgrade, Faculty of Biology) for providing the distribution map, BARNA PÁlL-GERGELY (Plant Protection Institute, Budapest) for his help in writing the manuscript as well as anonymous reviewers for their suggestions. I am grateful to the editor, ANDRZEJ LESICKI (Adam Mickiewicz University, Poznań, Poland), for his useful suggestions during manuscript processing.

Realtime Social Networking Service rapidly reveals distributions of non-indigenous land snails in a European capital. Bioinvasions Records 8: 782-792.

https://doi.org/10.3391/bir.2019.8.4.06

REISCHÜTZ P. L. 1988. Beiträge zur Molluskenfauna Thrakiens und Ostmakedoniens, II. Annalen des Naturhistorischen Museums in Wien, Serie B 90: 341356.

SON M. O. 2004. New findings of Tandonia kusceri (Pulmonata, Milacidae) in Ukraine. Vestnik Zoologii 38: 76.

SoN M. O. 2010. Alien mollusks within the territory of Ukraine: sources and directions of invasions. Russian Journal of Biological Invasions 1: 37-44. https://doi.org/10.1134/S207511171001008X

SYSOEV A., SCHILEYKO A. 2009. Land snails and slugs of Russia and adjacent countries. Pensoft Series Faunistica, Sofia.

TelebaK B., Stanković M. 2007. Prvi nalaz o puževima golaćima (Gastropoda) Specijalnog rezervata prirode „Zasavica“ (Srbija). Naučni skup «Zasavica 2007», 1. December 2007. godine, Sremska Mitrovica: 39-42.

TElEBAK B., BRAJKović M., ĆURČIĆ S. 2013. Contribution to the knowledge of the slugs (Gastropoda: Stylommatophora: Limacidae and Milacidea) from 
Montenegro. Bulletin of the Natural History Museum in Belgrade 6: 55-64.

https://doi.org/10.5937/bnhmb1306055T

TURÓcI Á., FeHÉr Z., KRÍzsIK V., PÁll-Gergely B. 2020. Two new alien slugs, Krynickillus melanocephalus Kaleniczenko, 1851 and Tandonia kusceri (H. Wagner, 1931), are already widespread ih Hungary. Acta Zoologica Academiae Scientiarum Hungaricae 66: 265282.

https://doi.org/10.17109/AZH.66.3.265.2020

WELTER-SCHULTES F. W. 2012. European non-marine molluscs, a guide for species identification. Planet Poster Editions, Göttingen.
WIKTOR A. 1987. Milacidae (Gastropoda: Pulmonata) - A systematic monograph. Annales Zoologici 41: 151-320.

WIKTOR A. 1996. The slugs of the former Yugoslavia (Gastropoda terrestria nuda - Arionidae, Milacidae, Limacidae, Agriolimacidae). Annales Zoologici 46: $1-110$.

Received: May 5th, 2021

Revised: October 8th / November 11th, 2021

Accepted: November 12th, 2021

Published on-line: December 6th, 2021 